\title{
NECROTIZING FASCIITIS OF BREAST IN POSTPARTUM PERIOD: CASE REPORT
}

\section{Fasciíte necrotizante de mama no puerpério: relato de caso}

\author{
Gisele do Couto Maldonado*, Daniel Meirelles Barbalho1, Fernanda Cristina Afonso Salum¹, \\ Melissa Iole da Cás Vita', Romulo Fassio Belem¹, Maria de Fátima Brito Vogt ${ }^{1}$
}

\section{ABSTRACT}

Necrotizing fasciitis is an aggressive infection that affects subcutaneous and superficial fascia by necrosis, more often found in the abdominal wall, perineum and extremities. Rare cases have been described in the breast and the literature points to breastfeeding and previous breast procedures as risk factors for this condition. We present a 27-year-old patient in postpartum period who presented a right nipple fissure associated to breastfeeding, that evolved to a local aggressive infection with extensive necrosis of fascia and mammary parenchyma characterized as necrotizing fasciitis. Our aim is to highlight the importance of early diagnosis, especially to differentiate from puerperal mastitis which has a different pathophysiology and treatment, as well as the need for appropriate therapy consisting of surgical debridement and broad spectrum antibiotics in order to avoid further complications and death.

KEYWORDS: Necrotizing fasciitis; breast diseases; mastitis; lactation disorders.

\section{RESUMO}

Fasciíte necrotizante é uma infecção agressiva que acomete o subcutâneo e fáscias superficiais por necrose, mais frequentemente encontrada em parede abdominal, períneo e extremidades. Raros casos foram descritos na mama e a literatura aponta a amamentação e procedimentos mamários prévios como fatores de riscos para essa condição. Apresentamos uma paciente no puerpério, de 27 anos, que apresentou uma fissura no mamilo direito associada à amamentação e que evoluiu com infecção local agressiva, com necrose extensa de fáscias e parênquima mamário caracterizada como fasciíte necrotizante. O trabalho visa apresentar a importância do diagnóstico precoce, principalmente com diferenciação para as mastites puerperais que possuem fisiopatologia e tratamento distintos, assim como a necessidade do tratamento adequado com desbridamento cirúrgico e antibioticoterapia de amplo espectro para evitar maiores complicações e o óbito.

PALAVRAS-CHAVE: Fasciíte necrosante; doenças mamárias; mastite; transtornos da lactação. 


\section{INTRODUCTION}

Necrotizing fasciitis is an aggressive infection that affects the subcutaneous and superficial fascia by necrosis, and can be found more frequently in the abdominal wall, perineum and extremities $^{1-3}$. Less than 20 cases were described in the breast and the literature points to breastfeeding and previous breast procedures as risk factors for this condition ${ }^{1}$. Therapeutic success depends on early diagnosis, institution of appropriate therapy and, especially, the differential diagnosis with puerperal abscesses secondary to lactational puerperal mastitis.

\section{CASE REPORT}

A 27-year-old female patient with three pregnancies, two deliveries and one abortion at seven days postpartum had a right nipple fissure associated with breastfeeding, mastalgia, and hyperemia. She was treated for puerperal mastitis with cephalexin and ibuprofen. After three days, she sought medical help at the University Hospital of Brasília (HUB) for fever and intense mastalgia. She was tachycardic (105 bpm), with arterial blood pressure of $107 \times 63 \mathrm{mmHg}$, axillary temperature of $36.6^{\circ} \mathrm{C}$ and $\mathrm{SaO}_{2} 95 \%$ in ambient air. She presented right breast with hyperemia extending to the abdomen, dorsum and contralateral breast, as well as a violaceous lesion surrounding the nipple-areolar complex with central necrosis (Figures 1 and 2).

The patient was admitted and ceftriaxone with clindamycin were initiated. Mammary ultrasound did not show any fluid collections or abscess. Admission laboratory tests showed mild leukocytosis with no left deviation, CRP and HSV with a significant elevation, pro-calcitonin in the moderate sepsis risk range $(0.698 \mathrm{ng} / \mathrm{mL})$ without further alterations. Nursing controls at 12 hours revealed fever of $39.1^{\circ} \mathrm{C}$, tachycardia (106

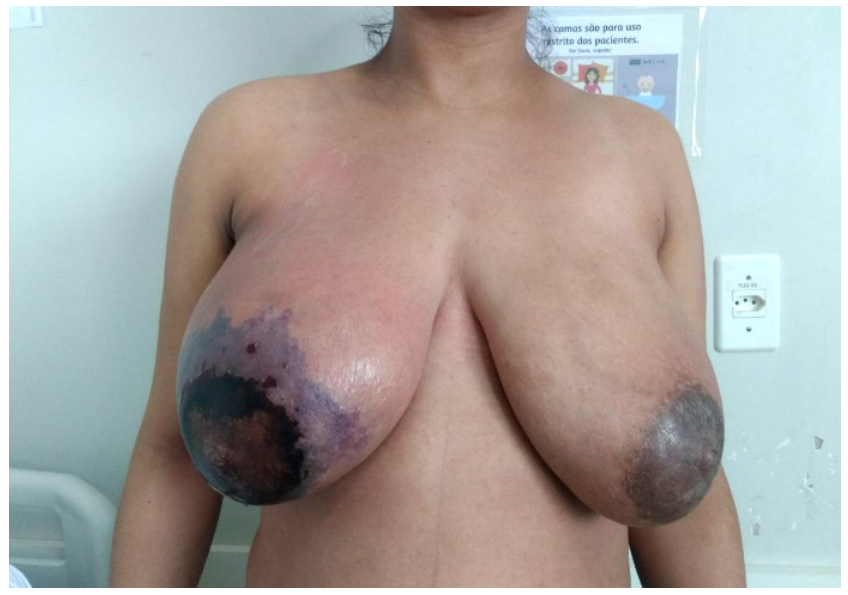

Figure 1. Hyperemyroid, edemaciate right breast, with necrolysis in the areola-papillary complex and a violaceous lesion surrounding its areola-papillary complex. to $116 \mathrm{bpm}$ ) and blood pressure trend to hypotension. New laboratory tests on the subsequent day showed leukocytosis with left deviation and still very high CRP and HSV. The hospital's infection control unit suggested the use of sodium piperacicline with tazobactam sodium, vancomycin and clindamycin. Breast surgery department was called and, after discussion with all medical staffs, opted for immediate surgical debridement. The patient was referred to the operating room after adequate information in the presence of her relatives and a signed consent form. Initially, breast conserving surgery was attempted. However, once perceived intraoperatively that the necrotic area was too extensive, a mastectomy was the only choice with removal of some necrotic level 1 axillary lymph nodes, but not a complete axillary dissection. The specimen was sent to pathology and breast parenchyma fragments, far from the skin, were sent to microbiology. A 2-cm window on the chest wall suture was left open to monitor the vitality of the pectoralis major muscle. Breastfeeding was inhibited by cabergoline and contralateral breast wrapping. After one day at ward, the patient was sent to the Intensive Care Unit (ICU) due to dyspnea, desaturation in ambient air and hypotension. A chest angiotomography showed moderate bilateral pleural effusion, later attributed to rigorous venous hydration. Following improvement of symptoms in the sixth day of ICU care, she was sent to ward, and discharged the next day after completing the seven-day schedule of broad-spectrum venous antibiotic therapy. The window suture was closed 14 days after the mastectomy.

Blood culture was negative, but breast fragments came positive with Streptococcus pyogenes and Staphylococcus warneri. Pathology report revealed acute mastitis with extensive necrosis measuring $10.5 \times 10.0 \mathrm{~cm}$ with abscessation of surrounding breast tissue (Figure 3), ulceration of the skin and overlying

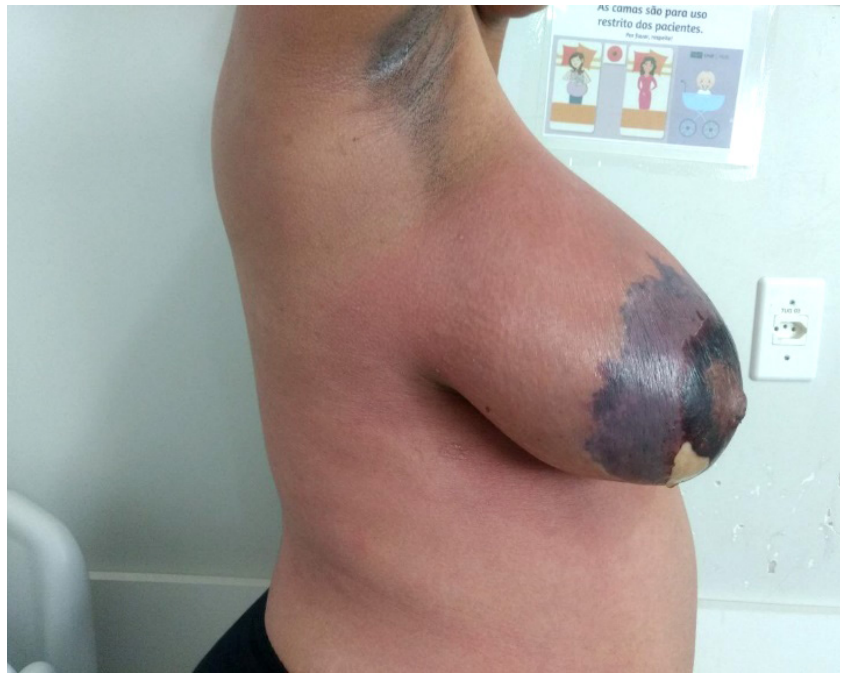

Figure 2. Hyperemia in the abdomen and dorsal region. 
nipple, lactational lobular hyperplasia and absence of neoplasia in the sample.

\section{DISCUSSION}

Necrotizing fasciitis is a rare aggressive infection ( 0.4 cases in 100,000 individuals) ${ }^{1}$ with high mortality rates (between 25 and $73 \%)^{2}$. It affects the subcutaneous and superficial fascia by necrosis, and most frequently affects the abdominal wall, perineum and extremities ${ }^{2,3}$. It may be primary or idiopathic when there is no evident reason such as skin tear, or secondary when the source of infection is known. The secondary one is most frequent and can be precipitated by laceration, cut, abrasion, contusion, burn, bite, subcutaneous injection or surgical scar ${ }^{2}$. It is associated with immunodeficiency due to: alcoholism, chemotherapy, malignant neoplasms, use of corticoids, malnutrition, diabetes mellitus, polytrauma and peripartum period ${ }^{1-4}$.

According to microbial etiology, it can be divided into three types. Type I is polymicrobial, with at least one obligate anaerobic bacterium associated with one or more facultative anaerobes (non-A group streptococci) and enterobacteria. This type is associated with abdominal or perineal infections. Type II usually occurs in extremities, such as hemolytic streptococcal gangrene, and is caused by group A haemolytic Streptococcus. It may be associated with Staphylococcus aureus ${ }^{1}$, and Streptococcus pyogenes is the most common bacteria found in approximately one third of cases of necrotizing fasciitis ${ }^{3}$. Type III is associated

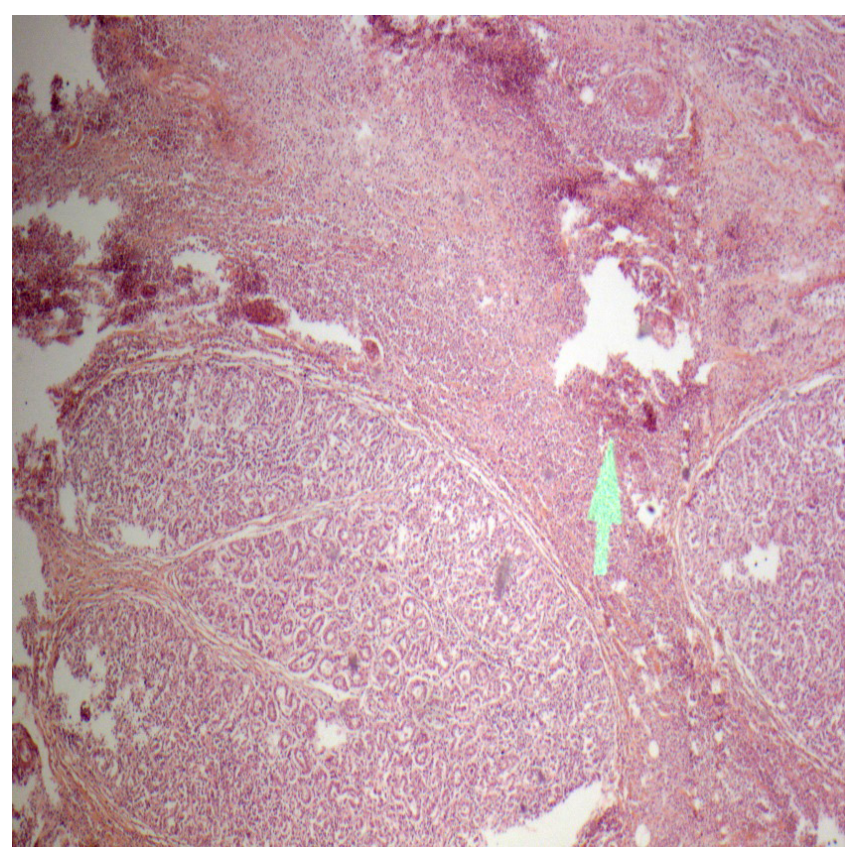

Figure 3. Parallel between the lobular duct and the focus of suppuration. Arrow detail for area of destruction and necrosis. with wounds made by fish or in contact with sea water ${ }^{1}$ caused by Vibrio vulnificus.

Mortality can be reduced by up to $10 \%$ with early diagnosis and intensive support, adequate surgical debridement and broad spectrum antimicrobial therapy ${ }^{2,3}$. In early phase, it may be an empirical combination of a carbapenem or other $\beta$-lactam antibiotics with betalactamase and clindamycin and, in severe patients, a combination of vancomycin to cover methicillin-resistant Staphylococcus aureus. Clindamycin, in addition to being bacteriostatic, inhibits toxins by Streptococcus that could lead to cardiovascular shock ${ }^{5}$.

Clinical presentation starts seven days after contamination process. An erythematous cellulitis appears, swollen and hot, preceded by intense local pain and systemic inflammatory response syndrome (SIRS) ${ }^{2}$. The diagnosis should always be suspected when there is a disproportion between pain and clinical findings in patients with SIRS. With evolution, the erythema spreads diffusely and, in short time, dark blueish gray spots appear with blisters containing serous fluids which later turn purple. From that moment, the infection is well defined in the subcutaneous space with free cutaneous necrosis, reaching much more the fascia and adipose tissue than the cutaneous level $^{6}$. The necrotic mechanism is unknown. Bacterial enzymes such as hyaluronidase might be responsible for the degradation of fascia, and lipases, for the degradation of fat tissue. Recent studies indicate that superantigens (SPE-A, SPE-B and SPE-C), secreted by certain strains of $b$-hemolytic Streptococcus, activate various cytokines, such as tumor necrosis factor alpha and beta, complement and cascade coagulation, yielding free oxygen radicals and nitric oxide, resulting in shock and failure of multiple organs ${ }^{7}$.

Necrotizing fasciitis of the breast is extremely rare. Only 16 cases are described in the literature and the majority of them has been associated with diabetes mellitus, previous invasive mammary procedures and breast cancer. In only six reports, women were not breastfeeding and had no evident risk factor ${ }^{1}$.

In the presented case, the patient had a tear in her right areola, which was probably the trigger for bacterial contamination and subsequent necrotizing fasciitis. Streptococcus pyogenes found in this case is in agreement with medical literature ${ }^{2}$. Staphylococcus warneri belongs to normal skin microbiota ${ }^{8}$. This was a type II case. Therefore, a combination of Piperaciclin sodium + tazobactam sodium was prescribed aiming the coverage of Streptococcus, vancomycin for a possible methicillin-resistant Staphylococcus aureus and clindamycin, specifically for the inhibition of toxins produced by Streptococcus ${ }^{2,5}$.

It is important to differentiate necrotizing fasciitis of the breast in the puerperium from puerperal mastitis, especially in the early stage, when there is still no skin involvement and may erroneously be confused with puerperal mastitis. Puerperal mastitis 
is the inflammatory process, infectious or not, in the breast of a breastfeeding woman ${ }^{9,10}$. It is frequent among women who breastfeed at about a $10 \%$ rate 9 . Risk factors include breast engorgement, scarce milk drainage, nipple excoriations or fissures, and history of previous puerperal mastitis ${ }^{10}$. The main agent is Staphylococcus aureus (50 to $60 \%$ of cases) ${ }^{9,11}$ followed by Streptococcus ${ }^{11}$. Patients usually respond well to milk draining and outpatient antibiotics ${ }^{12}$.

Unlike necrotizing fasciitis, where the bacterium penetrates through a tear and affects the mammary fascia causing tissue necrosis, puerperal lactational mastitis is an infectious process secondary to the milk stasis. This leads to inflammation of the subcutaneous tissue of the breast that may undergo bacterial colonization by the flora of the mother or the newborn oropharyn $x^{13}$. If the breast is not promptly milked, abscess formation usually occurs within 72 hours. Even in cases where abscesses occur, studies indicate the possibility of outpatient treatment with drainage by needles or catheters ${ }^{14-16}$.

This case highlights the differential diagnosis discussed above, which is eminently clinical. The presence of necrosis and severe pain should prompt the suspicion of necrotizing fasciitis. The prescription of antibiotics alone, without immediate debridement, augments the mortality rate. Puerperal mastitis, on the other hand, even with abscess formation, is treated successfully with antibiotics and outpatient drainage. Today's concern with breast aesthetics shouldn't halt adequate surgical debridement. Early diagnosis and appropriate therapy were fundamental for the success of treatment.

\section{CONCLUSION}

This study describes a rare case of necrotizing breast fasciitis occurring in the postpartum period. It is essential to perform early diagnosis with differentiation from puerperal mastitis. Necrotizing fasciitis, being a serious and rapidly progressive disease where time of evolution is inversely related to survival rates, justifies the use of broad-spectrum antibiotic therapy, surgical debridement and ICU support in order to avoid further complications and death.

\section{REFERENCES}

1. Ward ND, Harris JW, Sloan DA. Necrotizing Fasciitis of the Breast Requiring Emergent Radical Mastectomy. Breast J. 2017 Jan;23(1):95-9. https://doi.org/10.1111/tbj.12686

2. Taviloglu K, Yanar H. Necrotizing fasciitis: strategies for diagnosis and management. World J Emerg Surg. 2007;2:19. https://dx.doi.org/10.1186\%2F1749-7922-2-19

3. Fayman K, Wang K, Curran R. A case report of primary necrotising fasciitis of the breast: A rare but deadly entity requiring rapid surgical management. Int J Surg Case Rep. 2017;31:221-4. https://dx.doi.org/10.1016\%2Fj. ijscr.2017.01.049

4. Venkatramani V, Pillai S, Marathe S, Rege S, Hardikar J. Breast Gangrene in an HIV-Positive Patient. Ann R Coll Surg Engl. 2009 Jul;91(5):W13-4. https://doi.org/10.1308/147870809X401056

5. Kwak YG, Choi SH, Kim T, Park SY, Seo SH, Kim MB, et al. Clinical Guidelines for the Antibiotic Treatment for Community-Acquired Skin and Soft Tissue Infection. Infect Chemother. 2017 Dec;49(4):301-25. https://doi.org/10.3947/ ic.2017.49.4.301

6. McAdooGL,MonifGRG.ExpandingDiseaseSpectrumAssociated With Puerperal Mastitis. Infect Dis Obstet Gynecol. 1997;5(6):3769. https://dx.doi.org/10.1155\%2FS1064744997000689

7. Green RJ, Dafoe DC, Raffin TA. Necrotizing fasciitis. Chest. 1996 Jul;110(1):219-29. https://doi.org/10.1378/chest.110.1.219

8. Kamath U, Singer C, Isenberg HD. Clinical significance of Staphylococcus warneri bacteremia. J Clin Microbiol. 1992;30(2):261-4.

9. Scott JA, Robertson M, Fitzpatrick J, Knight C, Mulholland S. Occurrence of lactational mastitis and medical management:
A prospective cohort study in Glasgow. Int Breastfeed J. 2008;3:21. https://doi.org/10.1186/1746-4358-3-21

10. Sales AN, Vieira GO, Moura MSQ, Almeida SPTMA, Vieira TO. Mastite Puerperal: Estudo de Fatores Predisponentes. Rev Bras Ginecol Obstet. 2000 Dez [acesso em: 13 dez. 2017];22(10):62732. Disponível em: http://www.scielo.br/scielo.php?pid=S010072032000001000005\&script=sci_abstract\&tlng=pt http:// dx.doi.org/10.1590/S0100-72032000001000005

11. Beltrán Vaquero DA, Crespo Garzón AE, Rodriguez Bravo TC, Garcia Iglesias Á. Infectious mastitis: a new solution for an old problem. Nutr Hosp. 2015 Feb 7;31(Supl. 1):89-95. https://doi. org/10.3305/nh.2015.31.sup1.8714

12. Ulitzsch D, Nyman MK, Carlson RA. Breast abscess in lactating women: US-guided treatment. Radiology. 2004 Set;232(3):9049. https://doi.org/10.1148/radiol.2323030582

13. Betzold CM. An update on the recognition and management of lactational breast inflammation. J Midwifery Womens Health. 2007 Nov-Dez;52(6):595-605. https://doi.org/10.1016/j. jmwh.2007.08.002

14. Trop I, Dugas A, David J, El Khoury M, Boileau JF, Larouche $\mathrm{N}$, et al. Breast abscesses: evidence-based algorithms for diagnosis, management, and follow-up. Radiographics. 2011 Out;31(6):1683-99. https://doi.org/10.1148/rg.316115521

15. Dixon JM. Repeated aspiration of breast abscesses in lactating women. BMJ. 1988 Dez 10;297(6662):1517-8.

16. Chen CY, Anderson BO, Lo SS, Lin CH, Chen HM. Methicillinresistant Staphylococcus aureus infections may not impede the success of ultrasound-guided drainage of puerperal breast abscesses. J Am Coll Surg. 2010 Feb;210(2):148-54. https://doi. org/10.1016/j.jamcollsurg.2009.11.003 